\title{
Jim Burden’s Migratory Life in Willa Cather’s My Ántonia
}

\author{
DONG Qian \\ Beijing Information Science and Technology University, Beijing, China
}

\begin{abstract}
In My Antonia, Willa Cather explores the dilemma faced by modern Americans who yearn for the warmth of domestic life but also fear the confinements of domesticity. In order to live freely and avoid regulation and assimilation, they often choose to live a migratory life; almost all Americans have the experience of detaching themselves from one place and moving to another. Starting from this background, this paper intends to explore why Jim Burden chooses a continuous migratory life. The author analyzes Jim Burden's first migration which goes from Virginia to Nebraska. This migratory experience offers him freedom and the suicide of Mr. Shimerda illustrates the terror of being immobile and confined to one place. This paper argues that it is his desire for freedom and fear of immobility that urge him to escape from domesticity and live in continuous migration.
\end{abstract}

Keywords: migration, home, memory, past

\section{Introduction}

Willa Cather is best known for her depictions of immigrant experience on the American frontier and her nostalgia toward the American past in the West. Of all her pastoral novels, H. L. Mencken thought My Ántonia the most accomplished (Bohlke, 1986, p. 17). The issue of migration is thoroughly discussed in Joseph R. Urgo's Willa Cather and the Myth of American Migration (1995). He asserts that "migration is paradoxically the keystone of American existence, and migrants gather paradoxes as they move from one 'permanent' residence to the next" (Urgo, 1995, p. 13). Therefore, "the picture of life in the United States is a moving picture... the consciousness we share is migratory” (Urgo, 1995, p. 13). Based on the research done by earlier critics, this paper intends to explore Jim Burden's migration under the large context of the American migration to see why he chooses a migratory life and how important home is for a migrant.

\section{Migration as a Part of American Culture}

American culture is deeply rooted in migration. The one thing that all Americans have in common is an origin of migration, with ancestors detaching themselves from one place and move to another. The primary reason for migration to or within the United States is often dissatisfaction of some kind with the original circumstance and the desire to seek fortune in a new land. The malcontent people set out to a new world, which might just be another starting point of their next journey. It is these unsettled people, who contribute most to the nation's development.

Willa Cather is a real life example of migratory Americans: Born in Virginia, she spent her childhood in a prairie town, entered the University of Nebraska in Lincoln, took an editorial job in Pittsburgh and moved, 10 years later, to New York City, where she maintained a permanent address until her death. Instead of her family

DONG Qian, lecturer, master, School of Foreign Studies, Beijing Information Science and Technology University. 
cemetery plot in Red Cloud, she was buried in Jaffrey, New Hampshire, a place she favored for writing, particularly about western pioneers and their descendants. As Cather moved east, she brought the West with her, as an idea. In her imagination, she was a Virginian, a Nebraska pioneer, a southwestern adventurer, and a lover of the wilderness seeking refuge from the city. So if the question is to be asked: Where is Willa Cather's home? Perhaps the only safe answer is that she is an American. Migration and the consciousness it creates bring a special trait to American identity. The multi-placed past and selves make them quintessentially American.

In 1869, the Union Pacific was completed and the Burlington railroad entered Nebraska at Platsmouth. Cheap land, low interest rates, hope for a better future, and now improved transportation, all meshed to form an irresistible magnet attracting people who were unsatisfied with their living conditions and expected to try their fortune in the West. Like the Shimerdas portrayed in the novel, however, these people were totally unprepared for their new land; the handbills had not described the sight which met their eyes. Many people chose to return or migrate to other part of America to seek fortune, but those who stayed started their struggles for survival.

For those who chose to stay, their road seems to end there. After years of struggle in the land, they are rewarded with large farm land yielding great harvest. With a better financial condition, their children will have a better chance in the world. The younger generation will later move back east with the fortune made in the West, back to the city. The movement enhances the capital flows and again invigorates the development of America. As Urgo (1995) points out, "the version of American culture projected in the novels of Willa Cather is one of continuous movement, of spatial and temporal migrations, of intellectual transmission and physical uprooting” (p. 17). The movement of the land gave Cather the sentiment to write about the uprooting experience of the migrants in My Ántonia.

\section{Jim Burden's First Migration: An Introduction to Freedom}

The seemingly endless, empty plains of the American Midwest can provide an overwhelming experience to the newcomers who are more used to the reduced scale of the southern States or a European homeland. Jim says surprisingly: "I had never before looked up at the sky when there was not a familiar mountain ridge against it. But this was the complete dome of heaven, all there was of it” (Cather, 1988, p. 8).

As the novel's narrator, Jim Burden described his first migratory experience on the land as a total erasure of personality. Jim felt that the world was left behind, with all the familiar things and people that used to matter to him, and further described this sense of separation by "[breaking] down the known world into its constituent elements and [letting] go of each" (Holmes, 1999, p. 338). The "familiar mountain ridge” that used to obstruct Jim's view of the world is replaced by the "complete dome of heaven". Arriving on the new land, the old self is disappearing, with all the connections to the old home and the past in memory. However, Cather transforms her character's dissolution of self into "transcendence rather than annihilation” (O’Brien, 1987, p. 70). Unlike other migrants to the new land, Jim did not feel homesick and his old world memory ceased to exist on the open prairie. The readers seldom find Jim mention his life in Virginia, except in moments when memories of his past erupt from his consciousness and appear either in dreams or in the dreamy conditions induced by music and other artistic performances. Jim's past is driven inward, where it takes on a secret and parallel life.

Jim Burden's uprooting experience brings him an exhilarating sense of freedom and happiness. The annihilation of self is most vividly portrayed in the scene in his grandmother's garden, where Jim sits still under the sun like the pumpkins and does not expect anything to happen. Stripped of his old-world baggage, Jim has a "new feeling of lightness and content", a freedom of unattached, unrelated to anything stable. The lightness 
makes him feel that he might easily fly in the sky as the hawks do. The diminishing sense of identity is compensated by the lightness of freedom and the happiness of being part of something complete and great. At this primitive stage in his own life history, Jim Burden is open to the opportunity for a "natural" cessation of consciousness, an effortless crossing into the realm of all-ness that he experiences in his grandmother's garden (Cather, 1988, p. 14).

As Jim begins to acquire social experience, however, he, along with the prairie land that is imprinted with the marks of human history, cannot replicate the "all” feeling. After moving into town and being introduced to the social conventions, he loses his capacity to be dissolved into the elements as he learns to construct barrier between self and surrounding. He is a misfit in town, always feeling depressed and trying to escape from the repression. In telling the story of his growth and migration, Jim Burden shapes the material out of which countries are made and becomes a maker of the country.

For Jim Burden, the prairie is a land full of motion and inspiration for creation. When Jim breaks the bonds of his old world and enters the boundless universe of the new-world Nebraska, he discovers in the seemingly limitless possibilities of the terrain a susceptibility to change, not only in the seasons, but also in the motion of the land itself. The undulation of the grass gives the impression that the "whole country seem[s] somehow to be running" (Cather, 1988, p. 12). Jim's first response to the instability and unlimited potential of the landscape is excitement for freedom and creation. When Jim first arrived on the land, he marveled at the primitiveness of the land, describing the land as "the material out of which countries are made", a virgin land inviting exploration and cultivation. Similar to the land itself, Jim Burden shakes of the burden of past connections and the modeling of Virginian society and returns to a primitive self, opening up to new life experiences.

The freedom gained from his first migratory experience endows Jim with a sense of renewal and self-cultivation, which influenced Jim's life so that he can never settle permanently at any place. After three years of free life on the prairie, the life in the little town Black Hawk becomes repressive and lacking of motion and vitality to Jim Burden. The town men live a monotonous life with no life and no creativity. The static domestic life and the lacking of privacy in a little down restricted Jim so that he is glad to move to Lincoln and later to New York to pursue his intellectual development. Even after Jim got resettled in New York, taking a regular job and getting married, he could never stay for long. Jim Burden is a constant migrant, his life is on the road and the road created by himself never ends.

\section{Jim Burden's Migration and the Fear of Immobility}

If for Jim Burden the migration from Virginia to Nebraska means an erasure of identity, then the sense of loss is much stronger for immigrants. Oscar Handlin (1973) points out that as immigrants moved toward a new place, "their sights are fixed backward rather than forward. From the crossroad, the man, alone or with his wife and children, turns to look upon the place of his birth" (p. 34). One of the most important qualities of a successful migratory settler is the recognition that "to live in the old ways [is] to court failure and hardship" (Handlin, 1973, p. 84). New codes of conduct require new methods; what is left behind is not only a place, therefore, but a social, ethical, and perhaps even oral situation as well. The lack of adaptability or the unwillingness to give up the old ways of living is the cause of the death of Ántonia's father.

In their adaptation to the new land, language becomes the first obstacle for them to communicate with their new neighbor and establish new connections. Being unable to make their views heard, their past identities 
cannot be recognized by the community as if they never exist. The town people see all the immigrants as ignorant foreigners who cannot speak English. Even though Lena Lingard's grandfather is a clergyman, and much respected in Norway, Ántonia's father is better educated and knows more than the most respected and knowledgeable man in Black Hawk, what did it matter? All foreigners are the same, ignorant people who could not speak English (Cather, 1988, p. 129). That explains why Ántonia’s father is so eager to ask Jim to teach "[his] Ántonia” English, without which the foreigners cannot ask for advice, or even "to make their most pressing wants known" (Cather, 1988, p. 16). The moment they set foot on this new land, their past identities cease to exist. They have to learn new ways of living and build up new identities with connection to the new land. However, beautiful or glamorous the past is, it only exists in memory. The effect of being unable to walk out of the past and adapt to new life is lethal, of which Mr. Shimerda's suicide is a typical example.

Although Mr. Shimerda physically moved to Nebraska, his mind, trapped in a sense of dislocation, never left Bohemia. On their first visit to the Shimerdas' dwelling, Jim figures that Mr. Shimerda looks like the old portraits he remembered in Virginia, with his long hair "brushed out behind his ears". Besides, everything about Mr. Shimerda is in keeping with his dignified manner. He was also neatly dressed: "Under his coat he wore a knitted grey vest, and, instead of a collar, a silk scarf of a dark bronze-green, carefully crossed and held together by a red coral pin” (Cather, 1988, p. 18). Surviving in a new land is no easy matter, but the way he dresses himself shows that he has no intention of giving up his old way of living. When Jim's grandmother revisits their house in the winter time, the Shimerdas was in a worse condition: Mrs. Shimerda ties her feet up in rags for want of shoes; Ántonia and her sister have to sleep in an underground hole in order to keep warm; they have no food stored up for winter times. Even in such dire condition, Mr. Shimerda is still "neat and clean as usual, with his green neckcloth and his coral pin” (Cather, 1988, p. 50). He cannot accept the cruel reality of being completely deprived of the past and starting life anew. When he feels that he could no longer preserve his dignified manner, he chooses to commit suicide, leaving others to wish that his soul could go back to Bohemia, a past he never moves out of.

The suicide of Mr. Shimerda is the most indelible childhood memory for Jim Burden and has a far-reaching influence on his migratory life, through which Jim learns the importance of adaption and the deadly effect of homesickness. Unlike Mr. Shimerda, Jim Burden is well suited to his migration, as indicated by his initial reactions to Nebraska. His desire for freedom and fear of immobility urge Jim to escape from domesticity and live in continuous migration.

\section{Conclusion}

Moving west across the plains, Jim leaves even his parents' spirit behind and assures himself that he is not homesick. Throughout the novel, there is seldom Jim's memory of his Virginia past. His memory of the past, fills with the complex elements of desire and fear, and exposes Jim's fear of being essentially homeless and his simultaneous but conflicting desire to escape domestic regulation. If Mr. Shimerda is a person living in the past, Jim Burden is one always embracing the future and never let his past stand in his way of development.

\section{References}

Bloom, H. (Ed.). (1987). Willa Cather’s My Ántonia. New York: Chelsea House Publishers.

Bohlke, L. B. (Ed.). (1986). Willa Cather in person: Interviews, speeches, and letters. Lincoln: University of Nebraska Press.

Cather, W. (1988). My Ántonia. Boston: Houghton Mifflin Co..

Handlin, O. (1973). The uprooted. Boston: Little, Brown and Company. 
Holmes, C. D. (1999). Jim Burden’s lost worlds: Exile in My Ántonia. Twentieth Century Literature, 45(3), 336-346.

O’Brien, S. (1987). Willa Cather: The emerging voice. New York: Oxford University Press.

O’Brien, S. (1998). New essays on Cather's My Ántonia. Cambridge, Eng.: Cambridge University Press.

Ueda, R. (Ed.) (2006). A companion to American immigration. Oxford: Blackwell Pub..

Urgo, J. R. (1995). Willa Cather and the myth of American migration. Urbana and Chicago: University of Illinois Press. 